DOI: 10.36695/2219-5521.3.2019.33

УДК 347.7

М.М. ЯШАРОВА, М.А. ПАЛАМАРЧУК

Марія Миколаївна Яшарова, кандидат юридичних наук, доцент Національного технічного університету України «Київський політехнічний інститут імені Ігоря Сікорського»*

ORCID: 0000-0001-7648-8514

Марина Андріївна Паламарчук, студентка Національного технічного університету України «Київський політехнічний інститут імені Ігоря Сікорського»"**

\title{
ОКРЕМІ ПИТАННЯ ПРАВОВОГО РЕГУЛЮВАННЯ АВТОРСЬКИХ ПРАВ НА ПАРОДІІ,, КАРИКАТУРИ ТА ПОПУРІ
}

Постановка проблеми. Сфера творчої діяльності людини ніколи не вміщалися в суворо окреслені рамки будь-яких канонів чи норм - етичних, релігійних, правових. Таємниця творчості робить долю художніх творів та їхніх авторів непередбачуваними, велич таланту не підкоряється законам простору і часу. А спроби систематизувати різноманіття результатів художньої творчості, впорядкувати ієрархію стилів і течій в літературі й мистецтві, не мають кінцевого результату. Однак за останні століття людство все ж сформувало норми права інтелектуальної власності, які дають змогу охороняти і захищати права авторів і комерціалізувати результати їхньої творчості в правовому полі.

Аналіз останніх досліджень і публікацій. Важливі питання досліджуваної проблеми розглядали в багатьох працях вітчизняні учені, зокрема, Е.П. Гаврилов, В.О. Колосов, О.М. Коршакова, А.С. Штефан, B.М. Троцька, але публікації учених-цивілістів містять переважно фрагментарні положення з питань правового регулювання авторських прав на пародії, карикатури та попурі.

Формулювання мети статті. Виходячи з цих міркувань, мета даної статті полягає в проведенні правового аналізу поняття пародії, карикатури та попурі, змісту, а також визначення їх місця у праві інтелектуальної власності. Крім того, потребує вирішення теоретичне питання, виходячи з досвіду та практики зарубіжних країн.

Виклад основного матеріалу. Наразі чинним законодавством України в сфері авторського права не врегульовано питання щодо використання об'єктів авторського права в пародіях, карикатурах та попурі, однак раніше використання таких об'єктів розглядалося як створення «похідного твору», тобто створеного творчою переробкою вже існуючого твору без шкоди для його правової охорони.

Передусім зупинимося на поняттях «пародія», «попурі», «карикатура», введених в ст. 1 Закону про авторське право1:

- «попурі»- зазначається як музичний або інший твір, що є творчим підбором і розташуванням уривків інших правомірне оприлюднених творів або який імітує творчий стиль інших авторів чи виконавців або інших історичних епох;

- «пародія» - це твір, який є творчою переробкою іншого правомірно оприлюдненого твору або його частини, що за своїм змістом має комічний, сатиричний характер або спрямовується на висміювання певних подій або осіб;

- «карикатура» - твір образотворчого мистецтва, що створений внаслідок переробки іншого правомірно оприлюдненого твору або на основі персонажа твору чи імені персонажа твору, що за своїм змістом має комічний, сатиричний характер або спрямовується на висміювання певних осіб або подій.

Виходячи з викладеного вище ми бачимо, що відмінністю від похідних творів $є$ те, що матеріалом для створення похідних творів може бути будь-який існуючий твір, а для створення карикатур, попурі, пародій може використовуватись лише правомірно оприлюднений твір.

I тому правова охорони таких об'єктів з огляду права інтелектуальної власності є актуальним як для правозастосовної практики, так і для науки цивільного права, а особливо дослідження виключних майнових прав на такі об’єкти. А за відсутності практичних і теоретичних напрацювань зумовлюють і необхідністю правового аналізу визначення поняття пародії, карикатури та попурі, змісту, а також визначення кваліфікуючих ознак і урівноваження прав та інтересів правовласника й суспільства.

(C) М.М. Яшарова, М.А. Паламарчук, 2019

* Maria Yasharova, Ph.D., Associate Professor, Associate Professor of the National Technical University of Ukraine «Igor Sikorsky Kyiv Polytechnic Institute»

${ }^{* *}$ Marina Palamarchuk, student of the National Technical University of Ukraine «Igor Sikorsky Kyiv Polytechnic Institute» 
Слід зазначити, що норми законодавства багатьох європейських країн передбачають можливість використання об'єктів авторського права без дозволу автора, але з обов'язковим позначенням імені автора в таких творах, як пародії, карикатури та попурі. Директива Свропарламенту № 2001/29 / СС «Про гармонізацію деяких аспектів авторського права і суміжних прав в інформаційному суспільстві» 2 також передбачає можливість встановлення національним законодавством допустимості використання таких об'єктів без дозволу автора в разі, якщо таке використання здійснюється для створення пародій, карикатур та попурі.

У Законі України «Про авторське право і суміжні права» ${ }^{3}$ повинно бути визначено правову норму, яка регламентує використання оригінальних творів для створення на їх основі пародій, карикатур та попурі. При цьому необхідно виключити можливість несумлінного використання такої законодавчої норми, і потенційного порушення авторських прав суб'єктів авторського права, встановивши чіткі критерії, за наявності яких допускається вільне використання творів без згоди автора. Визначені критерії, як: сумлінність використання твору автором пародії, карикатури чи попурі; творчі цілі і мотиви створення похідного твору; характер і обсяг використання «запозичення» твори; економічний ефект від використання твору повинні насамперед братися до уваги при наданні права на використання об'єктів авторського права для створення на їх основі іншого твору пародійного або карикатурного жанру, попурі.

Обмеження майнових прав інтелектуальної власності, в цілому є характерним для сфери авторського права: так, у ст. ст. 21-25 Закону України «Про авторське право і суміжні права» встановлено вичерпний перелік випадків вільного використання творів із обов'язковим зазначенням імені автора і джерела запозичення, одним із видів яких з прийняттям Закону України «Про внесення змін до Закону України «Про авторське право і суміжні права» щодо використання об'єктів авторського права в пародіях, попурі та карикатурах» від 05 жовтня 2016 р. № 1651-VIII ${ }^{4}$ стала пародія. На думку А. Штефан, вільне використання творів для створення пародії, карикатури, попурі є тим правовим компромісом, що забезпечує життєдіяльність зазначених жанрів 5 .

Окрім того, в новій редакції Закону України «Про авторське право та суміжні права» закріплено, що авторам пародій, попурі та карикатур не потрібно отримувати згоди автора оригінального твору на здійснення переробки, проте важливою умовою є зазначення при цьому автора первинного твору. Але при використанні власного права на авторство автор похідного твору також має не порушувати права на авторство творця первинного твору.

Згідно зі ст. 7 Закону України «Про авторське право та суміжні права» суб'єктами авторського права є: 1) автори творів, перелік, яких міститься; 2) спадкоємці; 3) особи, яким було передано авторські майнові права.

Відповідно до Цивільного кодексу України автором твору є фізична особа, зазначена звичайним способом як автор на оригіналі або примірнику творуб.

Відповідно до Закону України «Про авторське право та суміжні права» авторське право на твір виникає внаслідок факту його створення. Для виникнення і здійснення авторського права не вимагається реєстрація твору чи будь-яке інше спеціальне його оформлення, а також виконання будь-яких інших формальностей. А строк чинності майнових прав інтелектуальної власності на твір спливає через сімдесят років 3 моменту смерті автора чи останнього із співавторів, який пережив інших співавторів.

Отже, Закон України «Про авторське право та суміжні права» та Цивільний кодекс України не визначають окремого переліку ні прав авторів похідних творів, ні прав авторів карикатур, попурі, пародій, тому вважаємо, що переліки таких прав є тотожними з переліком прав авторів, що містяться у ст. ст. 14-15 Закону України «Про авторське право та суміжні права» та ст. ст. 438-441 Цивільного кодексу України (далі - ЦК України). Проте все ж прослідковується залежність прав автора похідного твору від дотримання прав автора оригінального твору, оскільки в разі порушення прав другого у першого прав взагалі не виникає.

Особисті немайнові права інтелектуальної власності у сфері авторського права завжди перебували у центрі уваги науковців. Дослідження їх правової природи, особливостей набуття, здійснення, правової охорони відбуваються постійно на різних рівнях.

Стаття 438 ЦК України закріплені особисті немайнові права автора, які деталізуються у ст. 14 Закону України «Про авторське право і суміжні права»7. Згідно зі ст. 438 ЦК України, окрім особистих немайнових прав інтелектуальної власності, закріплених у ст. 423 ЦК України, автору твору належать також право:

1) вимагати зазначення свого імені у зв'язку з використанням твору, якщо це практично можливо;

2) забороняти зазначення свого імені у зв'язку з використанням твору;

3) обирати псевдонім у зв'язку з використанням твору;

4) на недоторканність твору.

Водночас ст. 14 Закону України «Про авторське право і суміжні права» передбачено, що автору належать такі особисті немайнові права:

1) вимагати визнання свого авторства шляхом зазначення належним чином імені автора на творі і його примірниках та за будь-якого публічного використання твору, якщо це практично можливо;

2) забороняти під час публічного використання твору згадування свого імені, якщо він як автор твору бажає залишитись анонімом;

3) вибирати псевдонім, зазначати і вимагати зазначення псевдоніма замість справжнього імені автора на творі і його примірниках та під час будь-якого його публічного використання;

4) вимагати збереження цілісності твору і протидіяти будь-якому перекрученню, спотворенню чи іншій зміні твору або будь-якому іншому посяганню на твір, що може зашкодити честі і репутації автора. Також 
положеннями статті встановлено, що особисті немайнові права автора не можуть бути передані (відчужені) іншим особам.

Стаття 15 Закону України «Про авторське право та суміжні права» до майнових прав автора (чи іншої особи, яка має авторське право) відносить: а) виключне право на використання твору; б) виключне право на дозвіл або заборону використання твору іншими особами.

Але у новій редакції ч. 1 ст. 21 Закону України «Про авторське право та суміжні права» було доповнено таким пунктом: «...без згоди автора (чи іншої особи, яка має авторське право), але з обов’язковим зазначенням імені автора і джерела запозичення, допускається таке використання літературних, художніх, музичних та інших творів для створення на їх основі іншого твору в жанрі літературної, музичної чи іншої пародії, попурі або карикатури, а також використання такої пародії, попурі або карикатури». Виходячи 3 цього, можна зробити висновок, що законодавець припустився помилки, коли доповнив норму, оскільки відповідно до ч. 5 ст. 15 «Про авторське право та суміжні права» авторам використаних творів не виплачується винагорода за їх використання. Таким чином, закон створив умови для використання карикатур, які $є$ похідними творами, пародій, попурі будь-якою особою в книгах, газетах, журналах, соціальних мережах та інших місцях з будь-якою метою без згоди автора і без виплати винагороди.

Отже, відповідно до ч. 1 ст. 21 Закону про авторське право допускаються без згоди автора, але з обов'язковим зазначенням імені автора і джерела запозичення:

- використання літературних, художніх, музичних та інших творів для створення на їх основі іншого твору в жанрі літературної, музичної чи іншої пародії, попурі або карикатури;

- використання такої пародії, попурі або карикатури.

Щодо судової практики до прийняття даних змін, то дотримувались позиції про необхідність стягнення коштів за опублікування карикатур, здійснених без згоди автора оригінального твору. Зокрема, в справі № 367/3046/13-ц суд задовольнив позов та стягнув із засновника і видавця друкованого засобу масової інформації компенсацію за порушення авторських прав у зв'язку із опублікуванням карикатури без дозволу на це правовласника 8 .

Як показує досвід зарубіжних країн щодо урегулювання прав у сфері інтелектуальної власності, то постійно виникають ситуації, коли міжнародні норми в сфері охорони авторських прав не застосовуються належною мірою, а національні норми держав-учасників часто суперечать основним положенням та принципам міжнародного авторського права. Це стосується і правового регулювання охорони окремих об'єктів авторського права, а саме пародій на літературні, музичні та інші твори, а також карикатур (як пародій на твори образотворчого мистецтва) та попурі.

Французьке законодавство містить посилання, відповідно до якого не може бути заборонено створення пародій, карикатур та попурі на твір, який уже оприлюднено. Схожа позиція на дану проблематику і у бельгійських законодавців - створення карикатур, пародій, попурі не може бути заборонено автором первинного опублікованого твору, якщо при цьому дотримано умов доброчесності. Вірменське законодавство дозволяє вільне створення карикатур та пародій з використанням первинних творів, якщо при цьому нові ${ }^{9}$.

Законодавство Великобританії передбачає можливість створення пародій, карикатур та попурі 3 використанням творів, що захищені авторським правом, без необхідності отримання дозволу володільця прав об'єкти не є настільки схожими 3 попередніми, щоб їх можна було сплутати ${ }^{10}$.

Німецьке законодавство вказує, що для створення похідних творів архітектурних об'єктів, кінематографічних переробок, баз даних та творів образотворчого мистецтва потрібна згода автора первинного твору; щодо інших об'єктів, то потрібна згода перед опублікуванням або використанням створеного в результаті переробки твору.

У законодавстві Аргентини існує норма, відповідно до якої для створення пародії на твір, що не є суспільним надбанням, необхідне отримання згоди автора такого твору11.

Досить цікавим $є$ той факт, що згоди автора похідного твору на використання свого твору для подальшої переробки є недостатньо, оскільки такий твір також містить елементи твору, що був використаний автором для переробки. Тобто для того, щоб правомірно використовувати похідний твір з метою переробки, необхідна не лише згода автора такого твору, а й згода автора оригінального твору.

Важливою умовою при визначенні авторських прав є власне сам твір. Так, якщо твір є міжвидовою переробкою, то до нього можна застосовувати принцип «вичерпання прав», оскільки за своєю суттю це новий об'єкт. Отже, в такому випадку залежності від автора оригінального твору взагалі не має бути.

Висновки. Підсумовуючи усе вищевикладене, можна сказати, що автори пародії, попурі, карикатури користуються таким же комплексом майнових та немайнових авторських прав, як і автор первинного твору, проте більшість 3 них зберігають зв'язок з правами оригінального твору. Така особливість яскраво показує залежність авторів похідних творів від авторів оригінальних творів. Створення пародій, карикатур і попурі не повинно жодним чином перешкоджати авторам оригінальних творів здійснювати свої майнові права (використання, дозвіл або заборону використання).

Очевидно, що карикатура, пародія і попурі створюються в результаті творчої діяльності, яка приводить до створення нового об'єкта авторського права: новий самостійний об'єкт авторського права, створений на основі самостійного об'єкта авторського права іншої особи. Тому повністю розібратися, де межі комічного, сатиричного характеру твору, створеного, наприклад як пародія або карикатура, і незаконного використання чужого твору (наприклад у вигляді переробки, плагіату тощо) на практиці буде дуже нелегко. 
Проблема ефективності законодавства в різні часи привертала увагу багатьох вчених, переважно на рівні галузевих правових наук. Втім, єдиного алгоритму та методологічного підходу до ії вирішення не існує, як і не існує універсальних формальних критеріїв визначення ефективності законодавства. Однак це не означає неможливості їі вирішення, а шлях до визначення ефективності законодавства лежить через визначення його якості. Критерії якості доцільно визначити через певні ознаки законодавства, і тому актуальність означеної проблематики не викликає сумнівів, зважаючи на популярність пародійного жанру творчої діяльності в різних сферах авторського права.

1 Про внесення змін до Закону України «Про авторське право і суміжні права» щодо використання об'єктів авторського права в пародіях, попурі та карикатурах : Закон України. Відомості Верховної Ради Украӥни (ВВР). 2016. № 46. Ст. 781.

2 Directive 2001/29/EC of the European Parliament and of the Council of 22 May 2001 on the harmonisation of certain aspects of copyright and related rights in the information society. URL: http://eur-lex.europa.eu/LexUriServ/LexUriServ.do?uri=OJ:L:2001: 167:0010:0019:EN:PDF

3 Про авторське та суміжні права: Закон України від 23 грудня 1993 р. № 3792-XII. URL: https://zakon.rada.gov.ua/laws/ show/3792-12 (дата звернення: 28.12.2018).

4 Про внесення змін до Закону України «Про авторське право і суміжні права» щодо використання об' єктів авторського права в пародіях, попурі та карикатурах: Закон України від 05 жовтня 2016 р. № 1651-VIII. Відомості Верховної Ради Украӥни. 2016. № 46. Ст. 13.

5 Штефан А. Пародія на музичний твір з текстом в порядку вільного використання творів. Теорія і практика інтелектуальної власності. 2016. № 5. С. 66-74.

6 Цивільний кодекс України: Закон України від 16 січня 2003 р. № 435-IB. URL: https://zakon.rada.gov.ua/laws/show/43515 (дата звернення: 26.12.2018).

7 Цивільне право України: загальна частина / за ред. професорів І.А. Бірюкова, Ю.С. Заіки. Київ: Алерта. 2014. С. 273.

8 Рішення Ірпінського міського суду Київської області від 14 серпня 2013 р. по справі № 367/3046/13-ц. URL: http://www. reyestr.court.gov.ua/Review/33253902

9 Липцик Д. Авторское право и смежные права / пер. с фр.; предисловие М.А. Федотова. Москва: ЮНЕСКО, 2002.789 с.

10 The Copyright and Rights in Performances (Quotation and Parody) Regulations 2014. URL: http://www.legislation.gov.uk/ ukdsi/2014/9780111116029)

11 Липцик Д. Вказана праця.

\section{References:}

Pro vnesennia zmin do Zakonu Ukrainy «Pro avtors'ke pravo i sumizhni prava» schodo vykorystannia ob'iektiv avtors'koho prava v parodiiakh, popuri ta karykaturakh : Zakon Ukrainy. Vidomosti Verkhovnoi Rady Ukrainy (VVR). (2016). 46, St. 781 [in Ukrainian].

Directive 2001/29/EC of the European Parliament and of the Council of 22 May 2001 on the harmonisation of certain aspects of copyright and related rights in the information society URL:http://eur-lex. europa.eu/LexUriServ/LexUriServ.do?uri=OJ:L:2001: 167:0010:0019:EN:PDF

Pro avtors'ke ta sumizhni prava: Zakon vid 23.12.1993 № 3792-KhII - Redaktsiia vid 13.01.2016 // Baza danykh «Zakonodavstvo Ukrainy»/VR Ukrainy. URL: https://zakon.rada.gov.ua/lavs/shov/3792-12/ed20160113 (data zvernennia: 28.12.2018) [in Ukrainian].

Zakon Ukrainy «Pro vnesennia zmin do Zakonu Ukrainy "Pro avtors'ke pravo i sumizhni prava” schodo vykorystannia ob'iektiv avtors'koho prava v parodiiakh, popuri ta karykaturakh» vid 05.10.2016 № 1651-VIII. (2016). Vidomosti Verkhovnoi Rady Ukrainy. 46, St. 13 [in Ukrainian].

Shtefan, A. (2016). Parodiia na muzychnyj tvir z tekstom v poriadku vil'noho vykorystannia tvoriv. Teoriia i praktyka intelektual'noi vlasnosti. 5, 66-74 [in Ukrainian].

Tsyvil'nyj kodeks Ukrainy: Zakon vid 16.01.2003 № 435-IV. URL: http://zakon.rada.gov.ua/lavs/shov/435-15 [in Ukrainian].

Biriukov, I.A., Zaika Yu.S. (za red.). (2014). Tsyvil'ne pravo Ukrainy: zahal'na chastyna. K., Alerta [in Ukrainian].

Rishennia Irpins'koho mis'koho sudu Kyivs'koi oblasti vid 14 serpnia 2013 r. po spravi № 367/3046/13-ts. URL: http://www.reiestr.tsourt.gov.ua/Reviev/33253902 [in Ukrainian].

Lyptsyk, D. (2002). Avtorskoe pravo y smezhnie prava. M.: YuNESKO [in Ukrainian].

The Copyright and Rights in Performances (Quotation and Parody) Regulations 2014. URL: http://www.legislation.gov.uk/ukdsi/ 2014/9780111116029 [in English].

\section{Резюме}

Яиарова М.М., Паламарчук М.А. Окремі питання правового регулювання авторських прав на пародії, карикатури та попурі.

Стаття присвячена дослідженню абсолютно нового інституту авторського права на окремі об'єкти права інтелектуальної власності за законодавством України: пародії, карикатури, попурі, а також формулюванню висновків і пропозицій щодо розуміння цих понять.

Ключові слова: пародія на твір, об'єкти авторського права, попурі, карикатура обмеження майнових прав інтелектуальної власності.

\section{Резюме}

Яшарова М.Н., Паламарчук М.А. Отдельные вопросы правового регулирования авторских прав на пародии, карикатуры и попурри. 
Статья посвящена исследованию абсолютно нового института авторского права на отдельные объекты права интеллектуальной собственности по законодательству Украины: пародии, карикатуры, попурри, а также формулировке выводов и предложений относительно понимания этих понятий.

Ключевые слова: пародия на произведение, объекты авторского права, попурри, карикатура ограничения имущественных прав интеллектуальной собственности.

\section{Summary}

MariaYasharova, Marina Palamarchuk. Separate issues of copyright regulation for parody, caricature, and medley.

The sphere of creative activity of a person has never been placed in a strictly defined framework of any canons or norms - ethical, religious, legal. The mystery of creativity makes the fate of works of art and their authors unpredictable, the grandeur of talent does not obey the laws of space and time. And attempts to systematize the diversity of artistic outputs, to streamline the hierarchy of styles and currents in literature and art, have no end result. However, in recent centuries, humanity has still formed the rules of intellectual property rights, which allow to protect and protect the rights of authors and commercialize the results of their creativity in the legal field.

The article is devoted to the study of a completely new copyright institution for certain objects of intellectual property under the legislation of Ukraine: parodies, cartoons, potpourri, as well as formulation of conclusions and suggestions for understanding these concepts. The sphere of creative activity of people did not fit into the very narrow framework of be-canons of norms - ethical, religious, legal. That creativity to rob the share of art and that of authors who are inexpressible, the value of talent does not meet the laws of space for an hour. But try to systematize the rznomaniity of the results of artistic creativity, in the order of ipxrarhi style and flow in literature and mystery, do not have the end result. However, for the rest of the world, the people all formulated the norms of the rights of intellectual property, so as to allow the protection and seizure of copyright and commercial rights of the results of their creativity in the legal field.

Different laws of Ukraine in the field of copyright are regulated by the law on the subject of copyright laws in parodies, cartoons, and foolishness, but earlier in history it is clear and easy to read and write. legal protection.

Key words: parody of the work, copyright objects, a medley, caricature of intellectual property rights restriction.

DOI: 10.36695/2219-5521.3.2019.34

УДК 347.78

\section{К.С. ПОТУРАЙ}

Катерина Сереіївна Потурай, аспірант Інституту держави і права ім. В.М. Корецького НАН Украї$H u^{*}$

ORCID: 0000-0002-4670-4295

\section{ПРОБЛЕМАТИКА ВИЗНАЧЕННЯ АВТОРОМ ТВОРУ КІНЕМАТОГРАФІЇ ОСОБИ, ВІДМІННОЇ ВІД ФІЗИЧНОЇ ОСОБИ}

Постановка проблеми. На сьогоднішній день, у зв'язку з розвитком технологій, а також з розвитком практики застосування чинного законодавства України виникла необхідність дослідження особи автора твору кінематографії.

Аналіз останніх досліджень і публікацій. Частково дане питання досліджувалося О.М. Лук'янчиковою, Т.Ф. Мадагаєвою, водночас є необхідність грунтовного аналізу аспектів, які не були дослідженні у даних працях.

Формулювання мети статті. Мета даної статті полягає в тому, щоб дослідити можливість визнання інших осіб, відмінних від фізичних, авторами твору кінематографії, а також можливість укладення авторських договорів з такими особами в контексті чинного законодавства України.

Виклад основного матеріалу. На сьогоднішній день, у зв'язку з розвитком технологій, а також із розвитком практики застосування чинного законодавства України виникла необхідність дослідження особи автора твору кінематографії.

Бернська конвенція про охорону літературних і художніх творів у ст. 3 вказує, до кого з авторів застосовуються норми даної конвенції, а саме на громадян чи не громадян Союзуㄹ․ Таким чином можемо зробити висновок, що автором твору в розумінні Бернської конвенції є тільки фізична особа.

Відповідно до абз. 2 ст. 1 Закону України «Про авторське право і суміжні права» автор - це фізична особа, яка своєю творчою працею створила твір². Згідно з ч. 1 ст. 17 цього ж закону авторами аудіовізуального твору є: режисер-постановник; автор сценарію і (або) текстів, діалогів; автор спеціально створеного для аудіовізуального твору музичного твору з текстом або без нього; художник-постановник; оператор-постановник.

Одна і та ж фізична особа може суміщати дві або більше із наведених у цій частині авторських функцій.

(C) К.С. Потурай, 2019

* Kateryna Poturai, postgradiuate student of V.M. Koretsky Institute of State and Law of the NAS of Ukraine 